\title{
A dynamics appraisal of association among food Insecurity, women and child health: Evidence from developing countries
}

\author{
Shahzad Hameed, Wei Wei* and Nazish Chaudhary \\ *The School of Economics and Finance, Xi'an Jiaotong University, China. \\ ** Institute of Agriculture and Resource Economics, University of Agriculture Faisalabad, \\ Pakistan \\ *Shahzad_xjtu@outlook.com| wei_wei@xjtu.edu.cn $\mid$ nazishchaudhry145@gmail.com \\ Corresponding author: Shahzad_xjtu@ outlook.com
}

\begin{abstract}
ABSTRCT: Food insecurity has adverse consequences on women and child health in developing country. This study aims to fill the existing research gap by examining the dynamic impacts of food insecurity on women and child health outcomes, this study adds fresh large scale panel data; and unlike the existing studies this study estimates the short run dynamics on food insecurity on women as child health of developing countries. We found that there was a positive association between health expenditure, women fertility rate, women and child health outcome. There was a negative and statistically significant impact of food insecurity on women anemia in developing countries of Asia. Overall, the empirical analysis found that there was strong strength to be negative correlation between food insecurity and women and child health outcome, particularly in relation to women's participation as a productive labour force. The study suggests that there is need to multidimensional approach such as women and child health outcome, is needed to advance this type of research areas and should be followed broad spectrum policy interventions to improve the women and child health status as part of sustainable development goals.
\end{abstract}

Keywords: Food Availability, Food Access, Food Utilization, Food Stability, Asia

JEL code: J13, I18, I19, I11, Q18 


\section{Introduction}

Globally, debates on food security have involved women and child health as a key indicator to stimulate sustainable development (FAO,2018). Interesting, many researchers have explored a strong linked between women and child health and food insecurity, particularly in case of marginalized and deprived regions who have limited access of socioeconomic resources (Quisumbing and Pandolfelli, 2010) . Food security is meant to a state when all the people have economic and physical access to safe, healthy and adequate to fulfil their dietary requirements for healthy and energetic life (FAO, 2006). Measuring the dynamics of food security has been inadequate in developing countries as women and child health status and other socioeconomic and political factors, have not been examined into account (Aziz et al, 2020; Palmeira, 2020). Nevertheless, of the fact that almost half of global population and about $42 \%$ of the total labour force consists on women in under develop economies (FAO,2015), poor women and child health status remains a global issue, particularly in developing countries (UNDP, 2016). Women and children in low and middle income countries are more vulnerable to experience food insecurity (Alarcao, 2020; Sinclair et al, 2019). There is need to improve women and child health status to rise not only their education status but also nutritional status (Galiè et al., 2019). Worldwide, about 450 million adults have been facing alarming food insecurity since 2014 . From them, $6 \%$ are adult women and $14 \%$ are children. Women and Children in less developed countries are more likely to become food insecure than males as they take less calories and food intake compared to males (Broussard, 2019; Brown et al., 2018). In some countries, more food is preferably served to male as compare to female members in the household (Torheim and Arimond, 2013), which causes food insecurity (Von Grebmer et al., 2014). Moreover, food insecurity not only leads to low immunity, but also worsen the health status of women (Johnston et al., 2014). Similarly, the extent of food insecurity has inauspicious costs for children health status (Von Grebmer et al., 2014). There may be many factors behind extent of food insecurity, but the most important reason is their low income and disparity in intra- food intake (Laar and Aryeetey, 2015). The remaining factors involve limited household employment opportunities and education (Chimhowu, 2019; Po and Hickey, 2018; Bayissa et al., 2018). Food insecurity has had negative implications not only for health status but also economic development (Ariti et al., 2018). Globally, various studies on the topic of women health and empowerment and its impacts for food security as well as other development ends are 
being done in recent past (Farrukh et al, 2020; Tsiboe et al., 2018; Lentz, 2018; Suraningsih et al., 2016; Tibesigwa and Visser, 2016; Wiesmann, 2006).

However, so for so developing countries are concerned, no such research has been done previously, although impact of different factors on food (in)security have been examined by plethora of studies (Akram, 2018; Abrar ul haqet al., 2018; Naz et al., 2014; Bashir et al., 2013; Anila and Kiani, 2011; Ahmad and Farooq, 2010). The impact of food insecurity as potential factor on women and child health remains an unexplored area in developing countries. To be the best of our knowledge, no study has been estimated the short and long run impact of food insecurity on women and child health status, especially in developing countries. Therefore, present study fills the existing research gap in following ways; first, by examining the long run impact of food insecurity on women and child health, this study adds fresh large scale panel data; and second unlike the existing studies this study estimates the short run dynamics on food insecurity on women as child health of developing countries.

\section{Conceptual Framework}

There are multidimensional levels of concern when delving into consequences of food insecurity from national to household to household to individual and among individuals (Farrukh et al, 2020). At individual level, anyone food intake habit is influenced by expectations, self-motivation, personal efficacy and socioeconomic capability. At household level where resources for food is scared, choice of food depends on availability and access rather than nutritional value and content, whereas the intra-household food distribution will further affect food consumption through the surrounding culture and norms. The unfavourable health impacts of food insecurity in developing countries are wide-ranging affecting women and child's mental, physical, cognitive and nutritional well-being (Wiesmann, 2006). Food insecurity can have long term opposing effects on brain and cognitive development that is influenced by nutritional inadequacy pathways (Ariti et al., 2018). A pregnant woman with low quality of food, limited food intake, yet more nutrient requirements increases her own and her growing infant's risk of inadequate micronutrient and caloric intake. Food insecure children have a $150 \%$ more likely of anemia and iron deficiency, which leads to impairments in psychomotor, mental and cognitive development (Tsiboe et al., 2018). They have been found to have deficiency in magnesium, vitamin A and protein (Chimhowu, 2019). 
According to Laar and Aryeetey (2015) that under 3 year children in food insecure households had upraised odds ratios for respiratory infections as compare to food secure households. Similarly, another study of Johnston et al., (2014) found that food insecure household kids are 32\% more likely to be got ill and poor health.

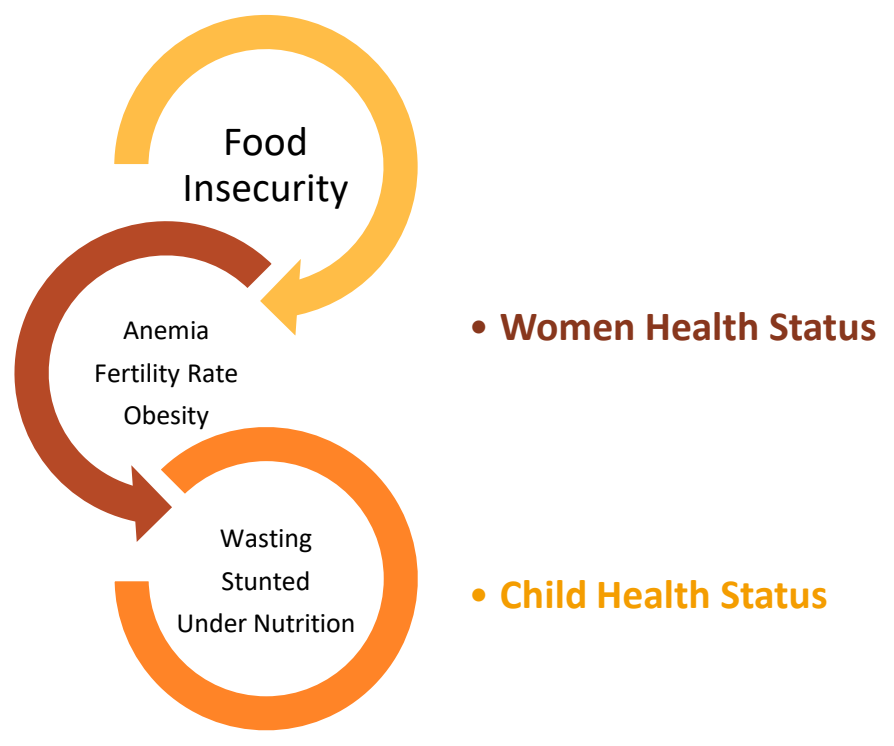

Figure 1 Conceptual linkages of food insecurity with women and child health (Source: Author's Estimation)

Mental health status is also affected by food insecurity (Broussard, 2019; Brown et al., 2018). Similarly, the children who are food insecure will themselves face physical and mental health problems. Therefore, this study fills the existing research gap by examining the long and short run effects of food insecurity on women and child health in the case of developing countries.

\section{Material and Methods}

To estimate the impact of Food security on women and child health status in the developing countries of Asia, study used the Panel GMM estimation Method presented by the Arellano and Bover, 1995; Blundell and Bond, 1998). To estimate the impact of Food security on women and child health status in the developing countries of Asia through the GMM estimation technique, we need to estimate the moment conditions for health status function $f($ Health_Status, $\theta)$ which is the proxy of six health variables related to women and child health.

$$
m\left(\theta_{0}\right) \cong E\left[f\left(\text { Health_Status, } \theta_{0}\right)\right]=0
$$


Where Health_Status is the proxy of of six health variables related to women and child health with the following moment condition $\theta \neq \theta_{0}$.

The estimation of the moment condition nothing except the simple average

$$
\hat{m}(\theta) \cong 1 / n \sum f(\text { Health_Status, } \theta)
$$

Minimize health status function $f$ (Health_status, $\theta$ ) with respect to the $\theta$, using the equation 2 . The resulted estimator will depend on choice of the norm function,

$$
\| \text { 媈 } \theta) \|_{W}^{2}=m(\theta)^{n} W n q(\theta)
$$

Where $\mathrm{W}$ in equation 3 is the weight norm function bases of given data set.

$$
\hat{\theta}=\underset{\theta \varepsilon \Theta}{\arg \min }\left(\frac{1}{n} \sum_{n=1}^{n} f(\text { Health_status }, \theta)\right)^{n} \hat{W}\left(\frac{1}{n} \sum_{n=1}^{n} f(\text { Health_status }, \theta)\right)
$$

The equation 4 is the final equation of the GMM which fulfil the following properties of GMM consistent, efficient, and asymptotically normal.

\subsection{Econometric Modeling}

\subsubsection{Women Heath Equations}

In Anemia _Women ${ }_{i j}=\beta_{i j, 1}$ Fnemia $_{-}$Women $_{t-1}+\beta_{i j, 2}$ Food_Supply $_{-} \beta_{i j, 3}$ Health_Exp. $+\beta_{i j, 4}$ Protein_Supply

$+\beta_{i j, 5}$ Dietary_Energy $+\beta_{i j, 6}$ PCGDP $+\beta_{i j, 7}$ Food_Im port $+\beta_{i j, 8}$ Pop _ water_avil $+\varepsilon_{i j}$

In Women $_{-}$Fertility $_{i j}=\beta_{i j, 1}$ Women $_{-}$Fertility $_{t-1}+\beta_{i j, 2}$ Food $_{-}$Supply $+\beta_{i j, 3}$ Health_Exp. $+\beta_{i j, 4}$ Protein Supply $_{-}$

$+\beta_{i j, 5}$ Dietary_Energy $+\beta_{i j, 6}$ PCGDP $+\beta_{i j, 7}$ Food_Im port $+\beta_{i j, 8}$ Pop_water_avil $+\varepsilon_{i j}$

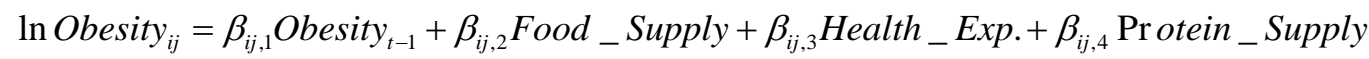

$+\beta_{i j, 5}$ Dietary_Energy $+\beta_{i j, 6}$ PCGDP $+\beta_{i j, 7}$ Food_Im port $+\beta_{i j, 8}$ Pop_water_avil $+\varepsilon_{i j}$

\subsubsection{Child Health Equations}

$\ln$ Child_Wasting $_{i j}=\beta_{i j, 1}$ Child_Wasting $_{t-1}+\beta_{i j, 2}$ Food_Supply $_{+} \beta_{i j, 3}$ Health_Exp. $+\beta_{i j, 4}$ Protein_Supply

$+\beta_{i j, 5}$ Dietary_Energy $+\beta_{i j, 6}$ PCGDP $+\beta_{i j, 7}$ Food_Im port $+\beta_{i j, 8}$ Pop_water_avil $+\varepsilon_{i j}$

$\ln$ Child_Stunded $_{i j}=\beta_{i j, 1}$ Child_Stundedt $_{t-1}+\beta_{i j, 2}$ Food_Supply $_{+} \beta_{i j, 3}$ Health_Exp. $+\beta_{i j, 4}$ Protein_Supply $+\beta_{i j, 5}$ Dietary_Energy $+\beta_{i j, 6} P C G D P+\beta_{i j, 7}$ Food_Im port $+\beta_{i j, 8}$ Pop _ water_avil $+\varepsilon_{i j}$ 
$\ln$ Child_under_Nutrition $_{i j}=\beta_{i j, 1}$ Child_under_Nutrition $_{t-1}+\beta_{i j, 2}$ Food_Supply $_{-} \beta_{i j, 3}$ Health $_{-}$Exp. + $\beta_{i j, 4}$ Protein_Supply $+\beta_{i j, 5}$ Dietary _Energy $+\beta_{i j, 6} P C G D P+\beta_{i j, 7}$ Food $\_$Im port $+\beta_{i j, 8}$ Pop_water_avil $+\varepsilon_{i j}$

Where i represent cross section (number of countries) and j represent data spam (1992-2019).

\subsection{Data Description and Sources}

To empirically analyze the impact of Food security on women and child health status in the developing countries of Asia (Pakistan, China, Bangladesh, India, Bhutan, Indonesia, Malaysia, Nepal, Sri Lanka, Korea, and Philippines), following study used the annul data taken from the Food and Agriculture Organization (FAO) for the period 2001 to 2018. Table 1 depicted the detail description and with description of all variables with the unit of variables used in the study to estimate the impact of Food security on women and child health status in the developing countries of Asia.

Table 1 List of Dependent and Independent Variables

\begin{tabular}{|c|c|c|c|}
\hline Sr. & Variables & Description & Unit \\
\hline 1 & $\begin{array}{l}\text { Prevalence of anemia among women of } \\
\text { reproductive age }\end{array}$ & (Anemia_Women) & (15-49 years) \\
\hline 2 & Women Fertility Rate & (women fertility) & (percent) \\
\hline 3 & Prevalence of obesity in the adult population & (Obesity) & (18 years and older) \\
\hline 4 & $\begin{array}{l}\text { Percentage of children under } 5 \text { years affected by } \\
\text { wasting }\end{array}$ & (Child wasting) & (percent) \\
\hline 5 & $\begin{array}{l}\text { Percentage of children under } 5 \text { years of age who are } \\
\text { stunted }\end{array}$ & (Child stunded) & (percent) \\
\hline 6 & Prevalence of undernourishment & (Child under nutrition) & $\begin{array}{l}\text { (percent) (3-year } \\
\text { average) }\end{array}$ \\
\hline 7 & Per capita food supply variability & (Food_Supply) & (kcal/cap/day) \\
\hline 8 & Per Capita Health Expenditure & (Health_Exp.) & (US \$) \\
\hline 9 & Average protein supply & (Protein_supply) & $\begin{array}{l}\text { (g/cap/day) (3-year } \\
\text { average) }\end{array}$ \\
\hline 10 & Average dietary energy supply adequacy & (dietary_energy) & $\begin{array}{l}\text { (percent) }(3 \text {-year } \\
\text { average) }\end{array}$ \\
\hline 11 & $\begin{array}{l}\text { Gross domestic product per capita, PPP, } \\
\text { dissemination }\end{array}$ & (PCGDP) & $\begin{array}{l}\text { (constant } 2011 \\
\text { international \$) }\end{array}$ \\
\hline 12 & Value of food imports in total merchandise exports & (Food_import) & $\begin{array}{l}\text { (percent) (3-year } \\
\text { average) }\end{array}$ \\
\hline 13 & $\begin{array}{l}\text { Percentage of population using at least basic } \\
\text { drinking water services }\end{array}$ & (Pop_Water_avil) & (percent) \\
\hline
\end{tabular}

Table 2 presented the estimated results of correlation matrix that explained the association of Food security (food supply, Protein supply and dietary energy intake as the proxies of the food security), 
women and child health status with other control variables (health expenditures, per capita income, availability of drinking water, and food imports) in the selected developing countries of Asia. The main diagonal of the table 2 correlation matrix shows the self-association of each. The reported result shows food security (food supply, Protein supply and dietary energy intake) negatively associated with the women health (anemia in women and women fertility rate).

Table 2 Results of Correlation Matrix

\begin{tabular}{|c|c|c|c|c|c|c|c|c|c|c|}
\hline & $\begin{array}{c}\text { ANEMI } \\
\text { A_WOM } \\
\text { EN }\end{array}$ & $\begin{array}{c}\text { Wome } \\
\text { n_fertil } \\
\text { ity }\end{array}$ & $\begin{array}{l}\text { OB } \\
\text { ESI } \\
\text { TY }\end{array}$ & $\begin{array}{c}\text { FOOD } \\
\text { Supp } \\
\text { ly }\end{array}$ & $\begin{array}{l}\text { Healt } \\
\text { h_Ex } \\
\text { p }\end{array}$ & $\begin{array}{c}\text { PROTEI } \\
\text { N_SUPP } \\
\text { LY } \\
\end{array}$ & $\begin{array}{c}\text { DIETAR } \\
\text { Y_ENER } \\
\text { GY } \\
\end{array}$ & $\begin{array}{c}\text { PC } \\
\text { GD } \\
\mathrm{P}\end{array}$ & $\begin{array}{c}\text { FOOD_ } \\
\text { IMPOR } \\
\text { T } \\
\end{array}$ & $\begin{array}{c}\text { POP_WA } \\
\text { TER_AV } \\
\text { IL } \\
\end{array}$ \\
\hline $\begin{array}{l}\text { ANEMIA } \\
\text {-WOME } \\
\mathrm{N}\end{array}$ & 1.00 & & & & & & & & & \\
\hline $\begin{array}{l}\text { Women_f } \\
\text { ertility }\end{array}$ & 0.74 & 1.00 & & & & & & & & \\
\hline $\begin{array}{c}\text { OBESIT } \\
\mathrm{Y}\end{array}$ & 0.92 & -0.98 & 1.00 & & & & & & & \\
\hline $\begin{array}{c}\text { FOOD_S } \\
\text { upply }\end{array}$ & -0.97 & -0.95 & 0.96 & 1.00 & & & & & & \\
\hline $\begin{array}{c}\text { Health_E } \\
\text { xp }\end{array}$ & -0.93 & -0.90 & 0.95 & 0.95 & 1.00 & & & & & \\
\hline $\begin{array}{c}\text { PROTEI } \\
\text { N_SUPP } \\
\text { LY }\end{array}$ & -0.97 & -0.98 & $0 . \overline{95}$ & 0.92 & 0.86 & 1.00 & & & & \\
\hline $\begin{array}{c}\text { DIETAR } \\
\text { Y_ENER } \\
\text { GY }\end{array}$ & -0.79 & -0.83 & $\begin{array}{c}- \\
0.73\end{array}$ & 0.67 & 0.58 & 0.86 & 1.00 & & & \\
\hline PCGDP & -0.99 & -0.98 & 1.00 & 0.98 & -0.96 & 0.94 & 0.72 & $\begin{array}{c}1.0 \\
0\end{array}$ & & \\
\hline $\begin{array}{l}\text { FOOD_I } \\
\text { MPORT }\end{array}$ & 0.49 & -0.54 & 0.43 & -0.45 & 0.35 & 0.43 & 0.59 & $\begin{array}{c}0.4 \\
5 \\
\end{array}$ & 1.00 & \\
\hline $\begin{array}{l}\text { POP_WA } \\
\text { TER_AV } \\
\text { IL } \\
\end{array}$ & -0.87 & -0.96 & 0.64 & 0.93 & -0.88 & 0.98 & 0.85 & $\begin{array}{c}0.9 \\
6\end{array}$ & -0.58 & 1.00 \\
\hline
\end{tabular}

\section{Empirical Results}

The table 3 presented the estimated empirical results of the impact of the food security on women health in selected developing countries of Asia. This study uses three proxies for estimating the women health: (1) prevalence of anemia in women, (2) women fertility rate, (3) obesity. Food supply, protein supply and dietary energy intake used as the proxies of the food security with other control variables (health expenditures, per capita income, availability of drinking water, and food imports).

The Asia is the largest and most populous continent of the world that facing great challenges of health and widespread hunger due to food insecurity which leads to various deficiency disorders 
like anemia, iodine, zine, vitamins A and D Akhtar (2016). Health expenditures is the opportunity cost to reduce the prevalence of anemia in women. The empirical result of table 3 , model 1 shows the negative electricity prevalence of anemia in women due to the health expenditure. One percent increase in the health expenditure can reduce the 0.71 percent anemia prevalence of anemia in women in selected developing countries of Asia. Subsequently model 2 and model 3 also suggested the positive association of health expenditure women fertility rate and obesity.

Deficiency of iron (Anemia) in women is the basic root due to the food insecurity and major public health concern in developing countries of Asia. Study used food supply, Protein supply and dietary energy intake as the proxies of the food security. The empirical result of table 3, model 1 shows that Anemia in women significantly linked with the food security. There exist negative and statistically significant association of women anemia with food supply, Protein supply and dietary energy intake. The reported results of table presented the elasticities of women anemia due to change in the food supply, Protein supply and dietary energy intake. One percent increase in the food supply reduce 0.02 percent prevalence of anemia in women in selected developing countries of Asia. While one percent protein supply reduces the 0.17 percent prevalence of anemia in women. One percent increase in dietary energy intake reduces 0.07 percent prevalence of anemia in women in selected developing countries of Asia. The empirical results are consistent with Ghose et. al. (2016) reported the relationship of food insecurity and women in anemia and (Skalicky et. al., 2006) estimated high likelihood ratio of suffering from anemia in women who face the problem of food insecurity in U.S. Subsequently empirical results show that per capita income, availability of drinking water services, and food imports which increase the domestic food supply of can reduce prevalence of anemia in women the in selected developing countries of Asia.

The food insecurity increases the birth defect risk among pregnant women, due to the compromised nutrition, depression, anxiety and stress. The empirical result of table 3, model 2 shows that women fertility rate positively associated with the food security. Food supply, Protein supply and dietary energy intake statistically significant affect the Women fertility rate in the selected developing countries of Asia. The empirical results of table 3, model 2 presented the elasticities of women fertility rate due to change in the food supply, Protein supply and dietary energy intake. One percent increase in the food supply increases 0.03 percent women fertility rate in selected developing countries of Asia. While one percent protein supply increases the 0.35 percent women 
fertility rate. One percent increase in dietary energy intake reduces 0.24 percent women fertility rate in selected developing countries of Asia. The empirical results are consistent with (Carmichael, et. al., 2007) suggsted the posstive association of food insurity and birth defect risk among pregnant women in U.S. and (Carmichael, et. al., 2007) estimated high maternal stress increases the birth defect risk among pregnant women in U.S. Subsequently estimated result shows that per capita income, availability of drinking water services, and food imports which increase the domestic food supply of can increase the fertility rate in women the in selected developing countries of Asia.

The food insecurity increases the associated risk of obesity (weight change) may be due to the lack of resources (poverty) that negatively affect the ability to maintain consistent access to nutritious foods. The empirical result of table 3 , model 3 shows that Obesity positively associated with the food supply food security, while negatively associated with Protein supply and dietary energy intake in the selected developing countries of Asia. The empirical results of table 3, model 3 presented the elasticities of Obesity due to change in the food supply, Protein supply and dietary energy intake. One percent increase in the food supply increases 0.06 percent prevalence of obesity in adult population in selected developing countries of Asia. While one percent protein supply reduces the 0.08 percent prevalence of obesity in adult population. One percent increase in dietary energy intake reduces 0.04 percent prevalence of obesity in adult population in selected developing countries of Asia.

Table 3 Impact of Food insecurity on Women Health

\begin{tabular}{|c|c|c|c|}
\hline Countries & \multicolumn{3}{|c|}{ Developing Countries } \\
\hline Variables & Model 1 & Model 2 & Model 3 \\
\hline LnAnemia_Women $_{\mathrm{t}-1}$ & $\begin{array}{c}\mathbf{0 . 7 5} \\
(0.16) \\
\end{array}$ & ---- & ---- \\
\hline Lnwomen fertility rate t- $_{1}$ & --- & $\begin{array}{l}\mathbf{0 . 8 2} \\
0.31 \\
\end{array}$ & --- \\
\hline LnObesity $_{\mathrm{t}-1}$ & ---- & ---- & $\begin{array}{l}\mathbf{0 . 6 0} \\
0.30 \\
\end{array}$ \\
\hline LnFood_Supply & $\begin{array}{c}\mathbf{- 0 . 0 2} \\
0.00 \\
\end{array}$ & $\begin{array}{l}\mathbf{0 . 0 3} \\
0.01 \\
\end{array}$ & $\begin{array}{l}\mathbf{0 . 0 6} \\
0.01 \\
\end{array}$ \\
\hline LnHealth_Exp. & $\begin{array}{c}\mathbf{- 0 . 7 1} \\
0.31\end{array}$ & $\begin{array}{l}\mathbf{0 . 4 5} \\
0.21\end{array}$ & $\begin{array}{l}\mathbf{0 . 6 5} \\
0.17\end{array}$ \\
\hline LnProtein_supply & $\begin{array}{c}-\mathbf{- 0 . 1 7} \\
0.08\end{array}$ & $\begin{array}{l}\mathbf{0 . 3 5} \\
0.09\end{array}$ & $\begin{array}{c}\mathbf{- 0 . 0 8} \\
0.08\end{array}$ \\
\hline Lndietary_energy & $\begin{array}{c}\mathbf{- 0 . 0 7} \\
0.03 \\
\end{array}$ & $\begin{array}{l}\mathbf{0 . 2 4} \\
0.09 \\
\end{array}$ & $\begin{array}{c}\mathbf{- 0 . 0 4} \\
0.04 \\
\end{array}$ \\
\hline LnPCGDP & -0.23 & 0.06 & 0.27 \\
\hline
\end{tabular}




\begin{tabular}{|c|c|c|c|}
\hline \multirow[b]{2}{*}{ LnFood_import } & 0.07 & 0.06 & 0.13 \\
\hline & $\begin{array}{c}\mathbf{- 0 . 0 3} \\
0.01 \\
\end{array}$ & $\begin{array}{l}\mathbf{0 . 0 7} \\
0.02 \\
\end{array}$ & $\begin{array}{c}\mathbf{- 0 . 0 1} \\
0.02 \\
\end{array}$ \\
\hline LnPop_Water_avil & $\begin{array}{l}\mathbf{0 . 6 9} \\
0.25 \\
\end{array}$ & $\begin{array}{l}\mathbf{0 . 8 4} \\
1.22 \\
\end{array}$ & $\begin{array}{c}\mathbf{- 0 . 2 5} \\
0.46 \\
\end{array}$ \\
\hline Constant & $\begin{array}{c}\mathbf{1 4 . 0 6} \\
1.20 \\
\end{array}$ & $\begin{array}{c}-\mathbf{- 2 6 . 1 2} \\
1.28 \\
\end{array}$ & $\begin{array}{l}\mathbf{4 . 5 0} \\
0.86 \\
\end{array}$ \\
\hline $\mathrm{N}$ & 167 & 171 & 164 \\
\hline
\end{tabular}

The table 4 reported the estimated empirical results of the impact of the food security on child health in selected developing countries of Asia. Study used three proxies for the child health, Percentage of children under 5 years affected by wasting, Percentage of children under 5 years of age who are stunted and Prevalence of undernourishment. While food supply, Protein supply and dietary energy intake as the proxies of the food security with other control variables (health expenditures, per capita income, availability of drinking water, and food imports). Child wasting, child Stunting and under nutrition is the key indicators of child health caused by the malnutrition. The children who are suffer wasted and stunted were the most at risk (Briend, et. al., 2015).

Table 4 Impact of Food Insecurity on Child Health

\begin{tabular}{|c|c|c|c|}
\hline \multirow{2}{*}{$\begin{array}{l}\text { Countries } \\
\text { Variables }\end{array}$} & \multicolumn{3}{|c|}{ Developing Countries } \\
\hline & Model 4 & Model 5 & Model 6 \\
\hline LnChild wastingt-1 & $\begin{array}{c}-\mathbf{- 0 . 5 8} \\
0.22\end{array}$ & ---- & ---- \\
\hline LnChild stundedt-1 & --- & $\begin{array}{l}\mathbf{- 0 . 7 9} \\
0.31\end{array}$ & --- \\
\hline LnChild under nutritiont-1 & --- & --- & $\begin{array}{l}\mathbf{0 . 7 2} \\
0.20\end{array}$ \\
\hline LnFood_Supply) & $\begin{array}{l}\mathbf{- 0 . 7 7} \\
0.33\end{array}$ & $\begin{array}{l}\mathbf{- 0 . 4 6} \\
0.27\end{array}$ & $\begin{array}{l}\mathbf{0 . 0 7} \\
0.01\end{array}$ \\
\hline LnHealth_Exp. & $\begin{array}{c}\mathbf{- 0 . 6 3} \\
0.12\end{array}$ & $\begin{array}{l}\mathbf{- 0 . 9 4} \\
0.35\end{array}$ & $\begin{array}{l}\mathbf{- 0 . 7 9} \\
0.38\end{array}$ \\
\hline LnProtein_supply & $\begin{array}{l}\mathbf{- 0 . 5 0} \\
0.72\end{array}$ & $\begin{array}{l}-\mathbf{- 0 . 5 3} \\
0.63\end{array}$ & $\begin{array}{l}-\mathbf{- 0 . 5 9} \\
0.18\end{array}$ \\
\hline Lndietary_energy & $\begin{array}{l}\mathbf{- 0 . 7 0} \\
0.85 \\
\end{array}$ & $\begin{array}{l}\mathbf{- 0 . 1 6} \\
0.26\end{array}$ & $\begin{array}{l}\mathbf{- 0 . 3 5} \\
0.13 \\
\end{array}$ \\
\hline LnPCGDP & $\begin{array}{l}\mathbf{- 0 . 0 8} \\
0.04\end{array}$ & $\begin{array}{l}\mathbf{- 0 . 0 4} \\
0.01\end{array}$ & $\begin{array}{l}\mathbf{- 0 . 5 1} \\
0.09\end{array}$ \\
\hline LnFood_import & $\begin{array}{c}\mathbf{- 0 . 0 8} \\
1.36\end{array}$ & $\begin{array}{r}-\mathbf{- 0 . 4 7} \\
0.74\end{array}$ & $\begin{array}{c}\mathbf{- 0 . 0 6} \\
0.03\end{array}$ \\
\hline LnPop_Water_avil & -0.09 & 0.70 & 0.32 \\
\hline
\end{tabular}




\begin{tabular}{c|c|c|c|c}
\multirow{2}{*}{ Constant } & 0.30 & 0.54 & 0.56 \\
\cline { 3 - 5 } & $\mathrm{-24.52}$ & $\mathbf{5 . 6 1}$ & $\mathbf{2 . 8 2}$ \\
& $\mathrm{N}$ & 3.36 & 1.59 & 0.32 \\
\hline \multicolumn{2}{c}{ legend: * $\mathrm{p}<0.10 ; * * \mathrm{p}<0.05 ; * * * \mathrm{p}<0.01$} \\
\hline
\end{tabular}

The empirical result of the table 3 , model 4 shows that one percent increase in the food supply reduces 0.77 percent children under 5 years affected by wasting. One percent increase in the Protein supply reduces 0.5 percent children under 5 years affected by wasting. Subsequently other control variables (health expenditures, per capita income, availability of drinking water, and food imports) also negatively associated with the children under 5 years affected by wasting.

Table 5 Results of Robustness Test

\begin{tabular}{c|c|c|c|c|c}
\hline \multicolumn{5}{c}{ Sargan test of over identifying restrictions } \\
\hline \multicolumn{5}{c}{ H0: over identifying restrictions are valid } \\
\hline Model 1 & \multicolumn{2}{c}{ Model 2 } & Model 3 \\
\hline chi2(193) & 71.06 & chi2(188) & 32.24 & chi2(191) & 23.40 \\
Prob > chi2 & 0.01 & Prob > chi2 & 0.03 & Prob > chi2 & 0.00 \\
\hline \hline
\end{tabular}

\begin{tabular}{c|c|c|c|c|c}
\hline \multicolumn{5}{c}{ Sargan test of over identifying restrictions } \\
\hline \multicolumn{5}{c}{ H0: over identifying restrictions are valid } \\
\hline Model 4 & \multicolumn{2}{c}{ Model 5 } \\
\hline chi2(211) & 63.31 & chi2(198) & 57.62 & chi2(207) & 71.15 \\
Prob > chi2 & 0.00 & Prob $>$ chi2 & 0.01 & Prob $>$ chi2 & 0.00 \\
\hline \hline
\end{tabular}

Table 5 reports the Sargan test for the verification of over identification problem and white noise error terms in the GMM model 1, model 2, and model 3. Table 6 reported the Sargan test for the verification of over identification problem and white noise error terms in the GMM model 4, model 5 , and model 6 . The empirical results of both tables reported that estimated value of the chi square greater than the critical value. So, GMM model 1 to model 6 correctly specified and error terms are uncorrelated in each model.

\section{Conclusion and Way forward}


Food insecurity has adverse consequences on women and child health in developing country. The implications of these socioeconomic insecurities lead to chronic diseases. Those women and children with chronic disease will not only tent to increase health expenditures, but are more likely to become burden on household and ultimately, to have decrease the household welfare. This study aims to fill the existing research gap in following ways; first, by examining the long run impact of food insecurity on women and child health, this study adds fresh large scale panel data; and second unlike the existing studies this study estimates the short run dynamics on food insecurity on women as child health of developing countries. We found that there was a positive association between health expenditure, women fertility rate and obesity. There was a negative and statistically significant impact of food insecurity on women anemia in developing countries of Asia.Overall there was strong strength to be negative correlation between food insecurity and women and child health outcome, particularly in relation to women's participation as a productive labour force. The study suggests that there is need to multidimensional approach such as women and child health outcome, is needed to advance this type of research areas and should be followed broad spectrum policy interventions to improve the women and child health status as part of sustainable development goals.

\section{References}

Ahmad, M., \& Farooq, U. (2010). The State of Food Security in Pakistan: Future Challenges and 
Coping Strategies. The Pakistan Development Review, 49, 903-923. doi:10.30541/v49i4IIpp.903-923

Akram, N. (2018). Women's Empowerment in Pakistan: Its Dimensions and Determinants. Social Indicators Research, 140. doi:10.1007/s11205-017-1793-z

Alarcão, V., Guiomar, S., Oliveira, A., Severo, M., Correia, D., Torres, D., \& Lopes, C. (2020). Food insecurity and social determinants of health among immigrants and natives in Portugal. Food Security. doi:10.1007/s12571-019-01001-1

Ariti, A., van Vliet, J., \& Verburg, P. (2017). Farmers' participation in the development of land use policies for the Central Rift Valley of Ethiopia. Land Use Policy, 71. doi: 10.1016/j.landusepol.2017.11.051

Ballard, T., Kepple, A., Cafiero, C., 2013. The food insecurity experience scale: develop- ment of a global standard for monitoring hunger worldwide. Tech. Pap. 116.https://doi.org/10.1016/j.measurement.2017.10.065. is

Bashir, M. K., Schilizzi, S., \& Pandit, R. (2013). Regional Sensitivity of Rural Household Food Security: The Case of Punjab, Pakistan. Journal of Animal and Plant Sciences, 23, 12001206.

Baumüller, H. (2015). Agricultural Innovation and Service Delivery through Mobile Phones: Analyses in Kenya.

Bayisenge, J. (2015). Changing Gender Relations? Women's Experiences of Land Rights in the case of the Land Tenure Reform Program in Rwanda.

Bayissa, F., Smits, J., \& Ruben, R. (2017). The Multidimensional Nature of Women's Empowerment: Beyond the Economic Approach: Multidimensionality of Women's Empowerment. Journal of International Development, 30. doi:10.1002/jid.3268

Chigbu, U. (2019). Anatomy of women's landlessness in the patrilineal customary land tenure systems of sub-Saharan Africa and a policy pathway. Land Use Policy, 86, 126-135. doi: 10.1016/j.landusepol.2019.04.041

FAO ,.2006. Food and Agricultural Organization of the United Nations (FAO) Agriculture and Development Economics Division, Policy Brief, June 2006, Issue 2.

FAO WFP, IFAD .2012. The State of Food Insecurity in the World 2012. Economic growth is necessary but not sufficient to accelerate reduction of hunger and malnutrition. Rome, FAO

FAO, 1996. Rome Declaration on World Food Security. World Food Summit, 13-17 September, 
1996, Rome. http://www.fao.org/3/w3613e/w3613e00.htm.

FAO, 2006. Food and Agriculture Organization (FAO). (2006). The state of food insecurity in the world. Food and Agriculture Organization of the United Nations, Rome.

FAO, 2008. Food and Agriculture Organization (2008). Deriving Food Security Information from National Household Budget Surveys: Experiences, Achievements, Challenges. Food and Agricultural Organization of the United Nations, Rome.

FAO, 2011. The state of food and agriculture. Women in agriculture: closing the gender gap for development. Food and Agriculture Organization, Rome, Italy.

FAO, 2014. The State of Food-Insecurity in the World: Strengthening the Enabling Environment for Food-Security and Nutrition. Food and Agriculture Organization of the United Nations, Rome.

FAO, IFAD, UNICEF, WFP, WHO, 2018. The State of Food Security and Nutrition in the World 2018. Building Climate Resilience for Food Security and Nutrition, the State of Food Security and Nutrition in the World. FAO, Rome.

Farrukh, M., Bashir, M. K., \& Rola-Rubzen, M. (2019). Exploring the sustainable food security approach in relation to agricultural and multi-sectoral interventions: A review of crossdisciplinary perspectives. Geoforum, 108, 23-27. doi:10.1016/j.geoforum.2019.11.012

Galiè, A., Teufel, N., Korir, L., Baltenweck, I., Girard, A., Dominguez-Salas, P., \& Yount, K. (2019). The Women's Empowerment in Livestock Index. Social Indicators Research, 142. doi:10.1007/s11205-018-1934-Z

Haq, M. A. u., Jali, M. R. M., \& Islam, G. M. N. (2018). Assessment of the role of household empowerment in alleviating participatory poverty among rural household of Pakistan. Quality \&amp; Quantity: International Journal of Methodology, 52(6), 2795-2814. Retrieved from https://EconPapers.repec.org/RePEc:spr:qualqt:v:52:y:2018:i:6:d:10.1007_s11135-0180710-0

Johnston, J., Fanzo, J., \& Cogill, B. (2014). Understanding Sustainable Diets: A Descriptive Analysis of the Determinants and Processes That Influence Diets and Their Impact on Health, Food Security, and Environmental Sustainability123. Advances in nutrition (Bethesda, Md.), 5, 418-429. doi:10.3945/an.113.005553

Laar, A., \& Aryeetey, R. (2014). Nutrition of women and children: Focus on Ghana and HIV/AIDS. 
In: N. Stein (Eds.), Public Health Nutrition Principles and Practice in Community and Global Health. In (pp. 187-210).

Lentz, E. (2018). Complicating narratives of women's food and nutrition insecurity: Domestic violence in rural Bangladesh. World Development, 104, 271-280. doi:10.1016/j.worlddev.2017.11.019

Lorente, D., Gokmenoglu, K., Taspinar, N., \& Cantos, J. (2019). An approach to the pollution haven and pollution halo hypotheses in MINT countries. Environmental Science and Pollution Research, 26. doi:10.1007/s11356-019-05446-X

Naz, M., \& Shahbaz, B. (2014). Role of rural women in agriculture and household food security in Faisalabad district. Pakistan Journal of Agricultural Sciences, 51, 757-761.

Palmeira, P., Mattos, R., \& Salles-Costa, R. (2020). Food security governance promoted by national government at the local level: a case study in Brazil. Food Security. doi:10.1007/s12571-019-01000-2

Po, J., \& Hickey, G. (2018). Local institutions and smallholder women's access to land resources in semi-arid Kenya. Land Use Policy, 76, 252-263. doi:10.1016/j.landusepol.2018.03.055

Quisumbing, A., \& Pandolfelli, L. (2010). Promising Approaches to Address the Needs of Poor Female Farmers: Resources, Constraints, and Interventions. World Development, 38, 581592. doi:10.1016/j.worlddev.2009.10.006

Sharaunga, s., \& Mudhara, M. (2016). Dimensions of Empowerment Influencing Women in KwaZulu-Natal to diversify away from agricultural-based livelihoods. Agrekon, 55, 103132. doi:10.1080/03031853.2016.1159586

Sinclair, K., Ahmadigheidari, D., Dallmann, D., Miller, M., \& Melgar-Quiñonez, H. (2019). Rural women: Most likely to experience food insecurity and poor health in low- and middleincome countries. Global Food Security, 23, 104-115. doi:10.1016/j.gfs.2019.04.006

Suraningsih, M., Hubeis, A., Sadono, D., Susanto, D., \& Saleh, A. (2016). Women Farmer's Participation And Empowerment To Support Family Food Self- Sufficiency. MIMBAR, Jurnal Sosial dan Pembangunan, 32, 319. doi:10.29313/mimbar.v32i2.1846

Tibesigwa, B., \& Visser, M. (2016). Assessing Gender Inequality in Food Security among Smallholder Farm Households in urban and rural South Africa. World Development, 88, 33-49. doi:10.1016/j.worlddev.2016.07.008

Torheim, L., \& Arimond, M. (2013). Diet quality, micronutrient intakes and economic 
vulnerability of women. In (pp. 105-115).

Tsiboe, F., Zereyesus, Y., Popp, J., \& Osei, E. (2018). The Effect of Women's Empowerment in Agriculture on Household Nutrition and Food Poverty in Northern Ghana. Social Indicators Research, 138, 89-108. doi:10.1007/s11205-017-1659-4

UNDP, 2016. Human Development Report 2016. United Nations Development Programme

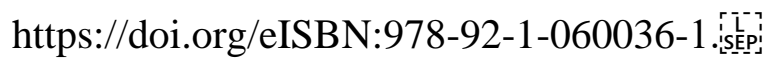

Wiesmann, D. (2006). A global hunger index: measurement concept, ranking of countries, and trends. 